4. 4. Монтессори M. http://studopedia.ru/13_143683_pedagogicheskayasistema-mariya-montessori.html

5. Корнер А.Ф. Теоретическое исследование пределов возможностей проетивных методик_http://bookitut.ru/Proektivnaya-psikhologiya.2.html

6. Беллак Л. О проблемах концепции проекции. Теория апперцептивного искажения http://www.libros.am/book /378652/proektivnayapsikhologiya\#sthash.62E5ODh1.dpuf http://www.libros.am/book/378652/proektivnaya-psikhologiya

7. Фромм Э. Анатомия человеческой деструктивности /http: //www.universalinternetlibrary.ru/book/15947/ogl.shtml

8. Венгер А.Л. Психологические рисуночные тесты: иллюстрированное руководство. - М.: ВЛАДОС-ПРЕСС, 2003. - 160 с.

9. Соколова Е.Т. Проективные методы исследования личности-М.: Издво Моск. ун-та, 1980. - 176 с.

10. Блейхер В.М., Крук И.В.. Патопсихологическая диагностика. - Киев, 1986.

\title{
СЛОЖНОСТИ ВХОЖДЕНИЯ В ПРОФЕССИЮ У НАЧИНАЮЩИХ ПСИХОЛОГОВ
}

Новикова С.С., Кагосян Ю.Ю.

$\begin{array}{ccccr}\text { Выпускники } & \text { психологических } & \text { ВУЗов } & \text { в } & \text { процессе своего } \\ \text { профессионального } & \text { самоопределения } & \text { сталкиваются } & \text { с } & \text { различными }\end{array}$ сложностями. В том числе и те, кто разу находит работу по специальности, их вход в профессию также протекает неоднозначно. Для начинающих специалистов-психологов характерна выраженная ориентация на реализацию личностного потенциала в рамках профессии при осознании ограниченных возможностей личностного и карьерного роста и низкой удовлетворенности содержательной стороной профессиональной деятельности (Андреева Н.С., 2001). Это связано со скрытым или нет потенциальным внутриличностныи конфликтом, который может осложнять профессиональную адаптацию молодых специалистов-психологов.

Трудности адаптации в профессии, с которыми сталкиваются начинающие психологи, описаны в различной литературе и ее анализ позволяет выделить наиболее типичные. Одна из основных проблем это не достаточная сформированность профессиональной идентичности, отсутствие конструктивной мотивации и неудовлетворенность окружающей средой теми или иными ее компонентами, что может привести к возникновения синдрома эмоционального выгорания.

Основной и чрезвычайно важной частью становления личности психолога является обретение профессиональной идентичности. Сформированная идентичность определяет систему координат, которая позволяет осмыслить профессиональный и личный опыт на начальном этапе вхождения в профессию, так как она расширяет Я-концепцию личности. 
Формирование профессиональной идентичности - это очень сложный процесс, который не всегда и не всеми осознается до конца. Е.А. Климов по этому поводу пишет о том, что у современного психолога формирование идентичности часто носит слабо осознанный характер. Очень актуальны проблемы адаптации психологов в различных отраслях профессиональной деятельности. Огромное значение имеет конструктивное протекание адаптации, так как при ее благоприятном завершении это позволит психологу быть максимально эффективным в выбранном виде деятельности и позволит реализовать свой потенциал в полной мере.

К сожалению, слабая осознанность начинающих специалистов замедляет формирование идентичности, как целостного понимания и представления о себе и своей роли в профессиональной деятельности, без этого крайне сложно понять, какое место психолог занимает в профессиональной среде, как он может реализовать свои знания и умения, полученные в процессе обучения.

Начинающий психолог проходит череду сомнений и тревог на пути своего профессионального становления, веру в свои возможности он обретает постепенно. В процессе своего становления молодому специалисту приходится делать много усилий, чтобы показать свои профессиональные, личностные качества. Эта профессия позволяет приобрести в процессе обучения такие необходимые качества и личностные особенности как рефлексивность, устойчивость и эмпатию. Эти качества являются положительными, но их наличие также может быть «фактором риска» в психоэмоциональной дезадаптации. (Реан.А.А.,1998).Исходя из этих факторов, мы можем говорить об этом времени как очень уязвимом для начинающего специалиста. В этот сложный период, вхождения в профессию, может быть очень важна поддержка более опытных коллег, которые помогут справиться с тревогой и ответить на интересующие вопросы. Кроме этого необходимо найти себе супервизора, с которым можно прорабатывать сложности, которые могут возникать в работе с клиентами.

Адаптация в профессии происходит со временем и в процессе того, как человек, учитывая свои возможности и способности, выбирает то направление, которое кажется ему подходящим для реализации его личностного потенциала.

Адаптация в профессии и формирование профессиональной идентичности - это самые важные стороны социализации и развития личности. Ссылаясь на О.В.Гавриченко, изучение профессиональной идентичности, как высшего пика самосознания в развитии личности профессионала позволяет выделить условия формирования позитивной идентичности, которая становиться условием успешности и эффективности профессионального развития.

Идентичность психолога имеет внутренние и внешние аспекты. К внешним аспектам мы можем отнести восприятие его коллегами и клиентами. Это может напрямую зависеть от того, как выглядит и какое впечатление производит психолог. Внутренними компонентами профессиональной идентичности являются те процессы и ощущения, которые мы называем самовосприятием и самосознанием. 
Современная психология исследует профессиональную идентичность в разных аспектах. Есть мнение, что данная проблема не решается только в рамках личностного подхода, который рассматривает данную проблему только как разновидность самоидентичности и определяется исключительно степенью тождественности идеального и реального образа профессионала.

Очень важным моментом является наличие пространства, которое будет для начинающего психолога условно «достаточно хорошей матерью» (Винникот), «среднеожидаемым окружением» ( Э.Эриксон) это способствует развитию идентичности ребенка его потребностей, возможностей и во многом схоже с потребностями начинающего психолога в ходе развития его профессиональной идентичности и профессиональной адаптации.

Скорость, с которой психолог проходит период адаптации и обретает профессионализм, опытность совершенна разная, хотя существую различные периодизации, где описывают временные промежутки и стадии вхождения в профессию. По нашему мнению прохождение периода адаптации во многом является индивидуальным процессом для каждого человека, так как в чем-то есть определенная схожесть с другими, но это облечено в уникальный опыт каждой личности.

Опыт практической работы, который приобретают молодые специалисты, позволяет сгладить очевидный для начинающих психологов разрыв между знаниями и возможностями их реализации в профессиональной деятельности. Однако Я-реальное все еще не включает в себя составляющую «Я-психолог». Результаты корреляционного анализа позволяют сформулировать особенности профессиональной идентичности молодого специалиста-психолога следующим образом: «Я пока еще не профессиональный психолог, но в идеале хотел бы быть им».

И все же в эту профессию идут люди определенного склада характера и с определенными наклонностями. Сторонние наблюдатели представляю психологию как набор методик, упражнений, приемов выучив, которые можно стать счастливым и успешным. Учеба в Вузе представляет собой сначала общую для многих профессий базу, а также набор довольно трудных дисциплин и это совсем не оправдывает ожидания студентов ожидающих увлекательную учебу. Психология серьезная, многоплановая и содержательная наука и работа психолога включает в себя огромный пласт знаний, умений и навыков, которые психолог получает благодаря учебе, работе и жизненному опыту.

\section{Литература:}

1. Винникотт. Семья и развитие личности. Мать и дитя. Екатеринбург, 2004. - C. 400

2. Психологическое сопровождении профессиональной деятельности начинающих психологов. Мет. Пособие.-СПб.:Изд-во РГПУ им. А.И. Герцена, 2003.-67c.

3. Кагосян Ю.Ю., Новикова С.С. Формирование профессиональной идентичности начинающего психолога /Сборник материалов XV Всероссийской научно-практической конференции. Под редакцией 
И.Б.Шуванова， В.П.Шувановой, С.А.Барановой, Ю.Э.Макаревской. 2016 Издательство Сочинский государственный университет, Сочи - С.216-218

4. Новикова С.С. Формирование профессионального мышления студентовпсихологов / Сборник материалов XIII Всероссийской научно-практической конференции. Под редакцией И.Б. Шуванова, С.В. Воронина, И.Г.Макаревской, Ю.Э. Макаревской, С.Н. Тесля, В.П. Шувановой. 2014 Издательство (Киров)

5. Новикова С.C. The levels of formedness of future of pedagogues/ psychologists' preparedness for professional orientation/ European Journal of Contemporary Education, №2 (8), 2014, C. 120-127

\section{К ВОПРОСУ ОБ ИССЛЕДОВАНИИ ВОЗМОЖНОСТЕЙ МУЗЫКОТЕРАПИИ КАК СРЕДСТВА КОРРЕКЦИИ ЭМОЦИОНАЛЬНОГО ВЫГОРАНИЯ ПЕДАГОГОВ}

Корнеева Е.Н., Ерофеева А.Г.

В настоящее время у лиц различных коммуникативных профессий, в частности, у педагогов, мы можем наблюдать ухудшение как физического, так и психического состояния здоровья. Высокие нагрузки, трудный контингент, с которым приходится работать, и множество иных факторов неизбежно ведет к хроническому стрессу, являясь предвестником эмоционального выгорания. Исходя из вышеизложенного, считаем данную проблему актуальной и требующей поиска новейших средств по предотвращению и коррекции данного феномена.

В исследованиях Н.В. Водопьяновой, К. Маслач и др. ранее было доказано, что представители образовательной сферы находятся в существенной группе риска относительно возникновения эмоционального выгорания [2; 6; 7].

Резюмируя все имеющиеся данные, нами была составлена программа исследования уровня эмоционального выгорания среди педагогов различных групп. В эти группы вошли представители начальной, средней школ, а также преподаватели ВУЗов г. Ярославля. В настоящее время обследовано 22 педагога, в дальнейшем планируется увеличение количества участников исследования.

Процентное соотношении участников нашего исследования можно увидеть на рисунке 1. 